\title{
Seashore paspalum in the Mediterranean transition zone: phenotypic traits of twelve accessions during and after establishment
}

\author{
Monica Gaetani, ${ }^{1}$ Marco Volterrani, ${ }^{1}$ Simone Magni, ${ }^{1}$ Lisa Caturegli, ${ }^{2}$ Alberto Minelli, ${ }^{2}$ \\ Claudio Leto, ${ }^{3}$ Salvatore La Bella, ${ }^{3}$ Teresa Tuttolomondo, ${ }^{3}$ Giuseppe Virga, ${ }^{3}$ Nicola Grossi ${ }^{1}$ \\ ${ }^{1}$ Department of Agriculture, Food and Environment, University of Pisa; ${ }^{2}$ Department of Agricultural Sciences, \\ University of Bologna; ${ }^{3}$ Department of Agricultural and Forest Sciences, University of Palermo, Italy
}

\begin{abstract}
The use of warm-season turfgrasses is consolidated in the transitional areas of Mediterranean countries and some field trials have provided information on the adaptability of seashore paspalum to Mediterranean environment. Nonetheless, little is known on the performance of the different commercial cultivars of Paspalum vaginatum in this climatic zone. Furthermore, considering the high degree of variability of this species, ecotypes have the potential to supply new plant material with desired turf characteristics. The research aimed at comparing growth characteristics and morphological traits of eight commercial cultivars of seashore paspalum (Platinum, Salam, SeaDwarf, Sea Isle 1, Sea Isle 2000, Velvetene, Marina and Sea Spray) and four ecotypes (CeRTES 101, CeRTES 102, CeRTES 103, CeRTES 104), during establishment and on mature turf grown in two Italian locations (Pisa and Palermo). Probably due to higher mean minimum temperatures a clear effect of location was recorded during the establishment year with fastest stolon growth rate and higher ground cover at 133 days after planting being registered in Palermo. Internode length and diameter, node density, horizontal stem density, turf quality and colour gave instead higher values in Pisa. On mature turf best colour ratings were of SeaDwarf and the ecotype CeRTES 104. The finest leaves were found in Sea Isle $2000(1.5 \mathrm{~mm})$ while the denser cultivars, and potentially the most wear resistant were Sea Isle 1, CeRTES 104, and Platinum. Top quality was scored for Sea Isle 1, Sea Isle 2000 and Platinum. Best performances for fall colour retention and spring green up were frequently associated
\end{abstract}

Correspondence: Marco Volterrani, Department of Agriculture, Food and Environment, University of Pisa, via del Borghetto 80, 56124 Pisa, Italy.

E-mail: marco.volterrani@unipi.it

Key words: Colour; Horizontal stem density; Node density; Turfgrass.

Received for publication: 4 July 2016.

Revision received: 7 December 2016.

Accepted for publication: 19 December 2016.

CCopyright M. Gaetani et al., 2017

Licensee PAGEPress, Italy

Italian Journal of Agronomy 2017; 12:808

doi:10.4081/ija.2017.808

This article is distributed under the terms of the Creative Commons Attribution Noncommercial License (by-nc 4.0) which permits any noncommercial use, distribution, and reproduction in any medium, provided the original author(s) and source are credited. with commercial cultivars. The relative ranking of the commercial cultivars for aesthetic and functional performance can be a tool for the decisions of turf managers while data of ecotype CeRTES 104 as to colour, shoot density and quality stimulate further research for the identifications of ecotypes with superior traits of visual quality and wear resistance.

\section{Introduction}

The use of warm season turfgrasses is a consolidated trend in the transitional areas of Mediterranean countries. Several experimental trials account for the adaptation of the main species at different latitudes of Italy, Spain and Turkey for applications ranging from park lawns to golf greens (Volterrani et al., 1997, 2010, 2012; Croce et al., 2004; Gomez de Barreda and Rivero, 2008; De Luca et al., 2008; Geren et al., 2009; Severmutlu et al., 2011; Grossi et al., 2014; Magni et al., 2014). While hybrid bermudagrasses have reached general acceptance in soccer pitches and golf courses, most of the turf managers consider seashore paspalum mainly for its tolerance to salt stress and limit its application to salt affected ornamental areas (Shahba, 2010; Duncan and Carrow, 2000). Research results reported by Trenholm et al. (1999, 2000) and Brosnan and Deputy (2009) have instead demonstrated that some cultivars of seashore paspalum can provide turfs with quality, wear resistance and damage recovery that are superior or comparable to some hybrid bermudagrass cultivars that are recognised reference standards for the turfgrass industry. The same studies report that wear resistance in seashore paspalum may be associated with some physiological and morphological traits and shoot density seems consistently associated with traffic tolerance.

Paspalum vaginatum displays a high degree of intraspecific variability with ecotypes giving a broad range of performances as to quality, tolerance to mowing, traffic, wear and other biotic and abiotic stresses (Trenholm et al., 1998) therefore additional information about the relative performance of different cultivars in the Mediterranean environment could help turf managers selecting the right cultivar. A further aspect of the interspecific variability of the species is a high diversity in naturally occurring populations (Duncan, 1997) and preliminary evaluation of ecotypes could increase the plant material available for turf establishment.

The aim of the research is to compare growth characteristics and morphological traits of eight commercial cultivars of seashore paspalum during establishment and on mature turf grown in two locations of the Mediterranean area in order to assess their relative turf performances and to preliminary evaluate their wear resistance. Furthermore, four ecotypes were included in the trial in order to evaluate their performance in comparison with improved commercial cultivars and potentially identify new plant material with desired turf characteristics. 


\section{Materials and methods}

The trial included 12 accessions of Seashore paspalum (Paspalum vaginatum Swartz). Eight were commercial cultivars of which 2 seed propagated (Marina and Sea Spray) and 6 vegetatively propagated (Platinum, Salam, SeaDwarf, Sea Isle1, Sea Isle 2000 and Velvetene). Four further accessions were vegetatively propagated ecotypes collected from naturally occurring populations. Collection sites of ecotypes were located in Italy (CeRTES 101=warm temperate, brackish water environment), Argentine (CeRTES 102=warm temperate, dune slacks; CeRTES 103=warm temperate, brackish water environment) and Egypt (CeRTES 104=Sinai peninsula, warm arid seashore sand).

The trial was carried out in two locations in Italy, at the

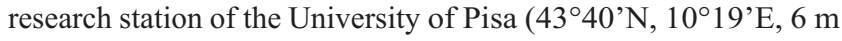
asl) and the research station of the University of Palermo $\left(38^{\circ} 06^{\prime} \mathrm{N}, 13^{\circ} 20^{\prime} \mathrm{E}, 50 \mathrm{~m}\right.$ asl). Soil type at Pisa was silt-loam (Calcaric Fluvisol, 28\% sand, 55\% silt and 17\% clay) with a $\mathrm{pH}$ of 7.8 and $18 \mathrm{~g} \mathrm{~kg}^{-1}$ organic matter while at Palermo soil type was sandy clay loam (Aric Regosol, 54\% sand, 23\% silt and 23\% clay) with a $\mathrm{pH}$ of 7.6 and $14 \mathrm{~g} \mathrm{~kg}^{-1}$ organic matter. Temperatures and precipitations recorded during 2013 and 2014 at the two trial sites are reported in Table 1. On 15 April 2013, all the accessions were propagated in the greenhouse in peat- honeycomb seed trays filled with $5-\mathrm{cm}^{3}$ peat for each plant. Vegetatively propagated cultivars and ecotypes were planted as single stolons and seeded cultivars were seeded as single seed following standard horticultural practices (Volterrani et al., 2008). On 13 May 2013 plants in the greenhouse were fertilised $\left(30 \mathrm{~kg} \mathrm{ha}^{-1} \mathrm{~N}, 10 \mathrm{~kg} \mathrm{ha}^{-1} \mathrm{P}\right.$, and $30 \mathrm{~kg} \mathrm{ha}^{-1} \mathrm{~K}$ ) using a soluble fertiliser. The field experimental area was treated applying oxadiazon [5-tert-butyl-3-(2,4-dichloro-5-isopropoxyphenyl)-1,3,4-oxadiazol-2(3H)-one] at $2.24 \mathrm{~kg} \mathrm{ha}^{-1}$ the day before planting. Experimental plots were 1.5 by $1.5 \mathrm{~m}$ with 0.5 $\mathrm{m}$ bare soil pathways arranged in a randomised complete-block design with four replications and single plants were transplanted in the centre of each plot. Transplant was accomplished on 3 June and 5 June 2013 in Pisa and Palermo respectively. From June to September 2013 plots received $25 \mathrm{~kg} \mathrm{ha}^{-1} \mathrm{~N}, 10 \mathrm{~kg} \mathrm{ha}^{-1} \mathrm{P}$, and 20 $\mathrm{kg} \mathrm{ha}^{-1} \mathrm{~K}$ per month. To avoid genotype by mowing interaction plots were not mown during establishment year (2013). Weeds occurring during the trial period were manually removed. Encroachment of stolons into adjacent plots was avoided by the use of toothpicks that redirect the growing tip back toward the plot centre. After the establishment and the subsequent dormant period, plots were scalped at $1 \mathrm{~cm}$ the first week of March 2014 at both locations. Mowing was then suspended until end of April when full green up was recorded on all plots. From May to October 2014, mowing was carried out weekly with a reel mower (John Deere 20SR7; John Deere, Moline, IL, USA) at a cutting height of 2.5 $\mathrm{cm}$. Plots received $25 \mathrm{~kg} \mathrm{ha}^{-1} \mathrm{~N}, 10 \mathrm{~kg} \mathrm{ha}^{-1} \mathrm{P}$, and $20 \mathrm{~kg} \mathrm{ha}^{-1} \mathrm{~K}$ per month from May to August 2014. To avoid the encroachment of stolons into adjacent plots, the pathways were treated with glyphosate $\left(2.88 \mathrm{~kg} \mathrm{ha}^{-1}\right)$ every other week. Plots were not subject to soil cultivation or verticutting. The irrigation program was adjusted according to evapotranspiration rate and water applied as needed to encourage establishment in the 2013 growing season and to prevent wilt in the 2014 growing season. During establishment (2013) the following parameters were determined.

Ground cover was determined by taking weekly digital images of each plot with a Sony DSC-T70 digital camera from 14 to 56 days after planting (DAP), and from 63 to 133 DAP every other weeks. The camera was mounted on a tripod to ensure a consistent height from the soil surface of $1.0 \mathrm{~m}$. Digital images were saved in the JPEG format with an image size of 2592 by 1944 pixels and a resolution of $72 \mathrm{dpi}$. Camera settings included a shutter speed of $1 / 400 \mathrm{~s}$ and a focal length of $35 \mathrm{~mm}$. Green coverage data were obtained processing the digital images with the automated procedure described in Rasmussen et al. (2007) available as a web based software (www.imaging-crops.dk). Data are reported as plot surface percentage and refer to 133 DAP which was assumed as the end of active growth.

Stolon growth rate was measured from 28 to 56 DAP by marking with toothpicks the growing tip of two representative stolons in each plot. Elongation was measured weekly with a ruler and data are reported as average weekly elongation $\left(\mathrm{mm} \mathrm{week}^{-1}\right)$.

Internode diameter was measured by a micrometer (Digimatic, Mitutoyo Corp., Kawasaki, Japan) on ten node-internode units ran-

Table 1. Monthly mean air temperatures and precipitations during trial period in Pisa and Palermo.

\begin{tabular}{|c|c|c|c|c|c|c|c|c|c|c|c|c|}
\hline \multirow{4}{*}{ Month } & \multicolumn{6}{|c|}{ Pisa } & \multicolumn{6}{|c|}{ Palermo } \\
\hline & \multicolumn{4}{|c|}{ Mean air temperature $\left({ }^{\circ} \mathrm{C}\right)$} & \multicolumn{2}{|c|}{ Precipitations(mm) } & \multicolumn{4}{|c|}{ Mean air temperature $\left({ }^{\circ} \mathrm{C}\right)$} & \multicolumn{2}{|c|}{ Precipitations (mm) } \\
\hline & \multicolumn{2}{|c|}{2013} & \multicolumn{2}{|c|}{2014} & \multirow[t]{2}{*}{2013} & \multirow[t]{2}{*}{2014} & \multicolumn{2}{|c|}{2013} & \multicolumn{2}{|c|}{2014} & \multirow[t]{2}{*}{2013} & \multirow[t]{2}{*}{2014} \\
\hline & Max & Min & Max & Min & & & Max & Min & Max & Min & & \\
\hline January & 10.1 & 3.6 & 12.3 & 5.8 & 171 & 247 & 14.7 & 10.5 & 16.5 & 7.3 & 63 & 89 \\
\hline February & 9.7 & 1.2 & 14.1 & 7.7 & 92 & 131 & 13.7 & 8.1 & 17.1 & 9.4 & 105 & 103 \\
\hline March & 12.2 & 5.9 & 15.9 & 6.6 & 189 & 74 & 17.7 & 11.5 & 16.3 & 9.6 & 138 & 98 \\
\hline April & 18.3 & 9.5 & 17.8 & 9.2 & 78 & 32 & 20.5 & 13.9 & 18.5 & 12.9 & 44 & 66 \\
\hline May & 19.6 & 11.8 & 21.0 & 11.2 & 60 & 19 & 22.0 & 16.3 & 20.3 & 15.7 & 0 & 22 \\
\hline June & 24.6 & 13.9 & 26.9 & 16.0 & 16 & 34 & 23.7 & 18.8 & 26.8 & 19.6 & 0 & 0 \\
\hline July & 29.7 & 18.7 & 26.7 & 17.9 & 4 & 156 & 28.1 & 22.3 & 27.8 & 22.4 & 0 & 3 \\
\hline August & 30.1 & 18.6 & 26.8 & 18.0 & 20 & 2 & 29.5 & 23.8 & 29.1 & 23.2 & 29 & 2 \\
\hline September & 26.0 & 16.0 & 25.4 & 15.8 & 59 & 77 & 26.5 & 21.9 & 27.8 & 20.0 & 20 & 17 \\
\hline October & 21.4 & 14.5 & 22.6 & 13.3 & 111 & 90 & 25.1 & 19.2 & 25.0 & 18.8 & 102 & 0 \\
\hline November & 16.1 & 8.7 & 18.7 & 11.9 & 87 & 226 & 19.3 & 13.7 & 28.4 & 13.3 & 206 & 47 \\
\hline December & 12.2 & 3.1 & 14.3 & 6.9 & 26 & 121 & 16.1 & 10.5 & 16.9 & 12.0 & 108 & 127 \\
\hline Annual average values & 14 & & & & 76.7 & 80.4 & & & & & 68.0 & 48.0 \\
\hline
\end{tabular}


domly collected at 84 DAP. In order to take measurements only on mature tissues, the first four internodes from the stolon tip downward were discarded.

Internode length was measured with a precision Vernier caliper selecting internodes as for internode diameter.

Growing Degree Days (GDD) were calculated using the formula $\mathrm{GDD}=\left\{\left[\right.\right.$ Max. Temperature $\left({ }^{\circ} \mathrm{C}\right)+$ Min. Temperature $\left.\left.\left({ }^{\circ} \mathrm{C}\right) / 2\right]\right\}-5^{\circ} \mathrm{C}$, where $5^{\circ} \mathrm{C}$ is assumed as base temperature for seashore paspalum (Baskerville and Emin, 1969; Serena et al., 2012). Cumulated GDD were calculated from 3 June to 14 October and from 5 June to 16 October for Pisa and Palermo respectively to account for the same number of days after transplanting.

During the growing season after establishment (2014) the following parameters were determined.

Spring green-up was weekly estimated from 15 March to 30 April 2014 and expressed as percentage of green cover. Data reported refer to 14 April when some of the entries first exceeded the $90 \%$ threshold.

Colour (with a rating scale of $1=$ light green and $9=$ dark green) and quality (with a rating scale of $1=$ poorest and 9=best) (Morris and Shearman, 2008; Patton et al., 2009) were visually assessed at 30-day intervals from 1 May to 1 October. Data are reported as average over the observation period.

In the second week of October 2014, at both testing sites, on one $50 \mathrm{~cm}^{2}$ core sample per plot, the following parameters were determined: leaf width (20 fully expanded leaves per plot were measured with a precision Vernier caliper), shoot density (direct counting with data reported as shoot $\mathrm{n}^{\circ} \mathrm{cm}^{-2}$ ), horizontal stem density (stolons and rhizomes collected after soil washing were measured with a ruler and reported as $\mathrm{cm} \mathrm{cm}^{-2}$ ) and node density (nodes of stolons and rhizomes collected from the core samples were counted and reported as $\mathrm{n}^{\circ} \mathrm{cm}^{-2}$ ) (Roche and Loch, 2005; Volterrani et al., 2008).

Fall colour retention was weekly estimated from 15 November to 15 January 2015 and expressed as percentage of green cover.

Data were subjected to analysis of variance using CoStat software (Monterey, CA, USA). To test the effects of location, accession and their interaction a factorial combination was used. Significant different means were separated using Fisher's least significant difference (LSD) at the t-probability level of 0.05 . Only statistically significant results are reported and discussed.

\section{Results}

During establishment, stolon growth rate was significantly affected by location. Measurements taken from 28 to 56 DAP showed a higher rate in Palermo compared to that observed in Pisa, respectively being 7.6 and $6.4 \mathrm{~cm}^{-w_{e} \mathrm{k}^{-1}}$ (Table 2). A faster growth of stolon in Palermo yielded a significantly higher ground cover at 133 DAP compared to Pisa (55 and 42\% respectively). This result is in accordance with observations carried out on bermudagrasses where stolon growth rate has been found to represent a general predictor of establishment rate (Magni et al., 2014). Cumulative GDD recorded during stolon growth measurements (from 28 to 55 DAP) was $532^{\circ} \mathrm{C}$ in Pisa and $569^{\circ} \mathrm{C}$ in Palermo, while the cumulative data referring to the whole establishment period (from planting to $132 \mathrm{DAP}$ ) were $2243^{\circ} \mathrm{C}$ in Pisa and $2579^{\circ} \mathrm{C}$ in Palermo. Both the sets of data confirm Palermo as the warmest location and the observed growth performances are in line with this climatic parameter. At 84 DAP, despite a lower growth rate, stolons internodes were on average longer and thicker in Pisa compared to Palermo with respective internode length of 2.6 and $1.9 \mathrm{~cm}$ and internode diameter of 2.4 and $2.0 \mathrm{~mm}$. Based on this observation on Seashore paspalum, internode length seems not to effectively contribute to overall stolon elongation while internode tissue formation or reserve carbohydrates accumulation appears in contrast with stolon tip growth rate.

Growth rate, ground cover, internode length and internode diameter were also significantly affected by entry mean effect (Table 3). At the end of the first growing season (2013), comparable values of ground cover were reached by the vegetatively propagated cultivars Platinum, Salam, Sea Isle 1 and Sea Isle 2000 with $59,58,57$ and $51 \%$ ground cover respectively, the seeded cultivars (58\% for Sea Spray and 57\% for Marina), and by the CeRTES 101 ecotype (with $51 \%$ ). Ground cover determined as green coverage expansion of spaced plants helps ranking the relative performance of different entries and values not reaching $100 \%$ should not be interpreted as the inability of a given entry to reach full establishment within a growing season. The performance of the improved cultivar Velvetene and the ecotypes CeRTES 102 and Certes 104 was significantly poorer indicating a potential low establishment rate for these entries.

Wide variation is observed in stolon growth rate when considering the whole set of entries. Referring to the vegetative cultivars group, stolon growth was significantly faster in Velvetene than in Salam and SeaDwarf. Seeded entries gave equivalent rates of stolon growth while among the ecotypes CeRTES 103 had a superior growth of stolons compared to all the other entries of the same group. As to internode diameter, the finest stolons, with 1.8 and 1.9 $\mathrm{mm}$, were found in the vegetative cultivars Sea Isle 2000 and Salam respectively while ecotypes CeRTES 103 and CeRTES 101 had the thickest organs with diameters of 2.6 and $2.5 \mathrm{~mm}$ respectively (Table 4).

Highest values of internode length were found in vegetative (Velvetene and Sea Isle 2000) and seeded (Marina, Sea Spray) cultivars as well as among ecotypes (CeRTES 103). Lowest values were again recorded for vegetative entries (Salam, SeaDwarf and Sea Isle 1) and ecotypes (CeRTES 102) but not consistent association between this morphological trait and the stolon growth rate was observed.

The spring following the year of establishment, green up was extremely variable among accessions. Salam and Sea Isle 2000 had 93\% green coverage thus being the only two vegetative accessions reaching a significantly better performance compared to the whole

Table 2. Ground cover, stolon growth rate, internode length, and internode diameter determined during establishment (2013): location mean effect.

\begin{tabular}{lrrrr}
\hline Location & Ground cover $^{\circ}(\%)$ & Stolon growth rate $\left(\mathrm{cm} \mathrm{wk}^{-1}\right)$ & Internode length $(\mathrm{cm})$ & Internode diameter $\left(\mathrm{mm}^{\sharp}\right)$ \\
Pisa & $42^{* * *}$ & $6.4^{* *}$ & $2.6^{* * *}$ & $2.4^{* * *}$ \\
Palermo & $55^{* * *}$ & $7.6^{* *}$ & $1.9^{* * *}$ & $2.0^{* * *}$ \\
\hline
\end{tabular}

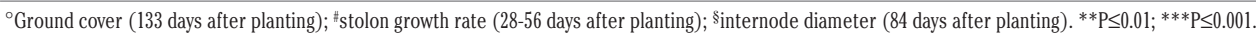


group of ecotypes. Vegetative and seeded cultivars gave similar green up with the only exception of Velvetene, whose percentage of green cover was significantly lower compared to the top performing vegetative cultivars Salam, Sea Isle 2000 and Platinum.

Through the period May-October 2014 the vegetatively propagated cultivar SeaDwarf had the best colour score of 7.1, thus being the darkest turf among the vegetative entries (Table 4). Seeded varieties were significantly different as to colour with Sea Spray reaching the value of 6.5 , not significantly different from some of the vegetative cultivars, and Marina having a score of 6.2 which as low as that of most ecotypes (CeRTES 101 and CeRTES 102 with 6.1). Differently from the other ecotype, Certes 104 had a score of 6.9, thus equalling for colour the performance of SeaDwarf. As a general trend, best quality performances were recorded for vegetative cultivars followed by seeded cultivars and ecotypes (Table 4). Sea Isle 1 and Sea Isle 2000 reached a mean value of 7.5 that was significantly higher compared to other vegetative cultivars like Salam, SeaDwarf and Velvetene. The seeded cultivars (Sea Spray and Marina) had a lower quality compared to all vegetative cultivars. Among ecotypes CeRTES 104 performed like some of the vegetative cultivars while CeRTES 103 had a quality non statistically different from that of the seeded cultivar Marina. The remaining ecotypes gave a poor quality through the observation period.

Leaf width values recorded in October 2014 were relatively uniform for almost all of the tested cultivars with blades having an average $1.75 \mathrm{~mm}$ width. The only cultivar with significantly finer leaves was Sea Isle 2000 with a $1.5 \mathrm{~mm}$ leaf width.

The vegetative cultivar Sea Isle 1 had the highest shoot density wit 5.5 shoots $\mathrm{cm}^{-2}$. While this parameter was not different from that of the two vegetative cultivars Sea Isle 2000 and Platinum, Sea Isle 1 stand was significantly denser compared to seeded varieties

Table 3. Ground cover, stolon growth rate, internode length, and internode diameter determined at establishment (2013): accession effect averaged across locations.

\begin{tabular}{|c|c|c|c|c|}
\hline Accession & Ground cover ${ }^{\circ}(\%)$ & Stolon growth rate ${ }^{\#}\left(\mathrm{~cm} \mathrm{wk}^{-1}\right)$ & Internode length (cm) & Internode diameter ${ }^{\S}(\mathrm{mm})$ \\
\hline \multicolumn{5}{|l|}{ Vegetative } \\
\hline Platinum & 59 & 7.5 & 2.3 & 2.1 \\
\hline Salam & 58 & 6.0 & 1.6 & 1.9 \\
\hline SeaDwarf & 40 & 5.7 & 1.9 & 2.0 \\
\hline Sea Isle 1 & 57 & 7.2 & 1.9 & 2.2 \\
\hline Sea Isle 2000 & 51 & 6.2 & 2.4 & 1.8 \\
\hline Velvetene & 37 & 7.8 & 2.7 & 2.0 \\
\hline \multicolumn{5}{|l|}{ Seeded } \\
\hline Marina & 57 & 9.2 & 2.7 & 2.1 \\
\hline Sea Spray & 58 & 8.0 & 2.4 & 2.2 \\
\hline \multicolumn{5}{|l|}{ Ecotypes } \\
\hline CeRTES 101 & 51 & 5.6 & 2.3 & 2.5 \\
\hline CeRTES 102 & 31 & 5.1 & 1.9 & 2.2 \\
\hline CeRTES 103 & 44 & 8.8 & 2.7 & 2.6 \\
\hline CeRTES 104 & 39 & 6.7 & 2.1 & 2.2 \\
\hline LSD 0.05 & 12 & 1.9 & 0.4 & 0.2 \\
\hline
\end{tabular}

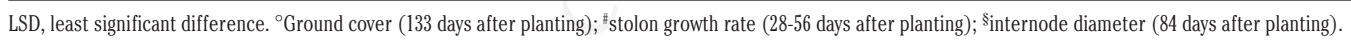

Table 4. Spring green-up, quality and colour, leaf width, shoot density, node density and horizontal stem density determined on mature turf: accession mean effect.

\begin{tabular}{|c|c|c|c|c|c|c|c|}
\hline Accession & $\begin{array}{c}\text { Spring } \\
\text { green up }{ }^{\circ}(\%)\end{array}$ & $\begin{array}{c}\text { Colour\# } \\
(1-9)\end{array}$ & $\begin{array}{l}\text { Quality } \\
\text { (1-9) }\end{array}$ & $\begin{array}{l}\text { Leaf } \\
\text { width }^{\S} \\
(\mathrm{mm})\end{array}$ & $\begin{array}{c}\text { Shoot } \\
\text { density } \\
\left(\mathrm{cm} \mathrm{cm}^{-2}\right)\end{array}$ & $\begin{array}{c}\text { Horizontal stem } \\
\text { density }^{\S} \\
\left(\mathrm{n}^{\circ} \mathrm{cm}^{-2}\right)\end{array}$ & $\begin{array}{l}\text { Node density } \\
\qquad\left(\mathrm{n}^{\circ} \mathrm{cm}^{-2}\right)\end{array}$ \\
\hline \multicolumn{8}{|l|}{ Vegetative } \\
\hline Platinum & 90 & 6.7 & 7.3 & 1.8 & 4.5 & 3.9 & 4.2 \\
\hline Salam & 93 & 6.8 & 7.0 & 1.8 & 4.4 & 3.6 & 3.5 \\
\hline SeaDwarf & 85 & 7.1 & 7.0 & 1.8 & 4.2 & 2.5 & 3.0 \\
\hline Sea Isle 1 & 83 & 6.8 & 7.5 & 1.7 & 5.5 & 3.8 & 4.2 \\
\hline Sea Isle 2000 & 93 & 6.8 & 7.5 & 1.5 & 4.7 & 4.9 & 5.6 \\
\hline Velvetene & 77 & 6.7 & 6.9 & 1.8 & 3.7 & 3.1 & 2.7 \\
\hline \multicolumn{8}{|l|}{ Seeded } \\
\hline Marina & 88 & 6.2 & 6.0 & 1.7 & 3.9 & 3.3 & 3.2 \\
\hline Sea Spray & 81 & 6.5 & 6.4 & 1.7 & 3.7 & 4.2 & 4.2 \\
\hline \multicolumn{8}{|l|}{ Ecotypes } \\
\hline CeRTES 101 & 75 & 6.1 & 5.2 & 1.8 & 2.9 & 3.5 & 2.9 \\
\hline CeRTES 102 & 68 & 6.1 & 5.1 & 1.7 & 2.8 & 2.0 & 2.0 \\
\hline CeRTES 103 & 73 & 6.5 & 5.9 & 1.8 & 3.3 & 2.9 & 2.7 \\
\hline CeRTES 104 & 78 & 6.9 & 6.7 & 1.7 & 5.0 & 2.7 & 2.5 \\
\hline LSD 0.05 & 13 & 0.3 & 0.5 & 0.2 & 1.1 & 1.0 & 1.2 \\
\hline
\end{tabular}

LSD, least significant difference. ${ }^{\circ}$ Percentage of green colour on 14 April 2014; “ visual estimation based on 1-9 scale, mean values 1 May-1 October 2014 ; ${ }^{\S} 15$ October 2014. 
and most ecotypes. The ecotype CeRTES 104 was not different from Sea Isle 1 and also denser of the seeded varieties and the rest of the ecotypes (Table 4).

Horizontal stem density highest values were recorded for Sea Isle 2000 and Sea Spray with 4.9 and $4.2 \mathrm{~cm} \mathrm{~cm}^{-2}$ ). Horizontal stems of these two entries, the first belonging to the vegetatively propagated cultivars, and the second to the seeded ones, were significantly denser compared to the vegetative entries SeaDwarf and Velvetene and most of the ecotypes (Table 4).

The vegetative cultivar Sea Isle 2000 had the highest node density of all entries with 5.6 nodes $\mathrm{cm}^{-2}$ while, among vegetative cultivars, Platinum and Sea Isle 1 had a higher density compared to the whole group of ecotypes. Both within the group of seeded entries and within the ecotypes no differences were detected. All ecotypes had a lower node density compared to the vegetative cultivars Sea Isle 2000, Platinum and Sea Isle 1 and the seeded cultivar Sea Spray (Table 4).

Fall colour retention was affected by the interaction between entry and location. In Pisa, with the only exception of Velvetene, vegetative cultivars and the seeded entry Sea Spray retained colour in fall better than ecotypes (Table 5). Probably due to milder temperatures in Palermo, plots had colour ratings that were equal or higher compared to Pisa. Among vegetative entries Salam had a significant better retention in Palermo thus maintaining the most prolonged green appearance over all entries. Substantial improvement of green retention due to location was recorded also for the ecotype CeRTES 104, whose performance became similar to that of many vegetative and seeded entries. Ecotypes CeRTES 101 and CeRTES 102 had a significantly better retention in Palermo compared to Pisa but this enhancement did not improve their relative performance among entries.

\section{Discussion}

The study has highlighted a noticeable variability of aesthetic and morphological traits among the compared entries. During the establishment year, stolon growth rate was on average faster in

Table 5. Fall colour retention determined on mature turf (30 December 2014): effect of interaction locations $\times$ accession.

$\begin{array}{lcc}\text { Accession } & \begin{array}{c}\text { Fall colour retention } \\ \text { Pisa }\end{array} \\ \text { Palermo }\end{array}$

LSD, least significant difference. ${ }^{\circ}$ Percentage of green colour.
Palermo and green cover at 133 DAP was also higher in Palermo compared to Pisa. The variation of seashore paspalum establishment speed as an effect of the total of favorable growing days is in accordance with results reported on putting green establishment (Stiglbauer et al., 2013).

Mature stands of vegetatively propagated entries gave in general the best performance as to quality and fall colour retention. Platinum, Sea Isle 1 and Sea Isle 2000 proved also relatively quick to establish and ranked among the denser entries. Sea Isle 2000 was first in the ranking also for texture and had an early spring green up.

Seed propagated entries Marina and Sea Spray were as quick to establish as the quickest vegetative cultivars, however colour, density and quality of the mature turf were lower.

Different from other turfgrass species, limited work can be found in literature reporting the result of evaluation programs including a wide number of seashore paspalum entries and little is known about their relative performance (Patton et al., 2010). The data obtained in this field trial could help filling this gap and provide turf growers with an unbiased support for cultivar selection.

\section{Conclusions}

Besides the standard parameters used to determine the performance of a turf, some of the data collected can provide a preliminary evaluation of entries' ability to tolerate sports use. Cultivars with high shoot density have the potential to tolerate wear better than others and might reasonably replace some bermudagrasses in trafficked turfs (Trenholm et al., 1999, 2000). CeRTES 104 was the only ecotype showing several desirable traits. While relatively slow to establish, its density and colour ranked among the top performing cultivars, thus producing a turf quality comparable to the best vegetative accessions with potentially superior wear tolerance. The comparison of a number of selected ecotypes with commercial cultivars provides a first screening of new plant material and may contribute to plant breeders' work for the selection of new cultivars.

\section{References}

Baskerville GL, Emin P, 1969. Rapid estimation of heat accumulation from maximum and minimum temperatures. Ecology 50:514-7.

Brosnan JT, Deputy J, 2009. Preliminary observations on the traffic tolerance of four seashore paspalum cultivars compared to hybrid bermudagrass. HortTech. 19:423-6.

Croce P, De Luca A, Mocioni M, Volterrani M, Beard J, 2004 Adaptability of warm season turfgrass species and cultivars in a Mediterranean climate. Acta Hort. 61:365-8.

De Luca A, Volterrani M, Gaetani M, Grossi N, Croce P, Mocioni M, Lulli F, 2008. Warm season turfgrass adaptation in Europe North of the $45^{\circ}$ parallel. Science and golf V. Proc. World Scientific Congress of Golf., Mesa, AZ, USA, pp. 496-501.

Duncan RR, 1997. Environmental compatibility of seashore paspalum (saltwater couch) for golf courses and other recreational uses. II Management protocols. Intl. Turf Res. J. 8:1216-29.

Duncan RR, Carrow RN, 2000. Seashore paspalum: the environmental turfgrass. J. Wiley \& Sons, Hoboken, NJ, USA.

Geren H, Avcioglu R, Curaoglu M, 2009. Performances of some warmseason turfgrasses under Mediterranean conditions. Afr. J. 
Biotechnol. 8:4469-74.

Gomez de Barreda D, Rivero S, 2008. Bermudagrass overseeding with 13 cool season turfgrasses in Spain. Proc. $1^{\text {st }}$ European Turfgrass Society Conference, Pisa, Italy, pp. 85-6.

Grossi N, Magni S, de Bertoldi C, Lulli F, Gaetani M, Caturegli L, Volterrani M, Croce P, Mocioni M, De Luca A, 2014. Establishment and winter management of "Miniverde" Bermudagrass for putting greens in Italy. Eur. J. Turfgrass Sci. 45:67-8.

Magni S, Gaetani M, Caturegli L, Leto C, Tuttolomondo T, La Bella S, Virga G, Ntoulas N, Volterrani M, 2014. Phenotypic traits and establishment speed of forty four turf bermudagrass accessions. Acta Agric Scand. 64:722-33.

Morris KN, Shearman RC, 2008. NTEP turfgrass evaluation guidelines. Available from: http://www.ntep.org/cooperator.htm

Patton A, Richardson M, Karcher D, Trappe J, 2009. 2007 NTEP Bermudagrass trial-year 3 results. Arkansas Turfgrass Report 2009. Ark. Ag. Exp. Stn. Res. Ser. 579:20-4.

Patton A, Richardson M, Karcher D, Trappe J, 2010. 2007 NTEP SeashorePaspalum trial - year 3 Results. Arkansas Turfgrass Report 2009. Ark. Ag. Exp. Stn. Res. Ser. 579:25-7.

Rasmussen J, Nørremark M, Bibby BM, 2007. Assessment of leaf cover and crop soil cover in weed harrowing research using digital images. Weed Res. 47:299-310.

Roche MB, Loch DS, 2005. Morphological and developmental comparisons of seven greens quality hybrid bermudagrass (Cynodon dactylon (L.) Pers. x C. transvaalensis Burtt-Davy) cultivars. Int. Turfgrass Soc. Res. J. 10:627-34.

Serena M, Leinauer B, Sallenave R, Schiavon M, Maier B, 2012. Turfgrass establishment from polymer-coated seed under saline irrigation. HortSci. 47:1789-94.
Severmutlu S, Mutlu N, Shearman RC, Gurbuz E, Gulsen O, Hocagil M, Karaguzel O, Heng-Moss T, Riordan TP, Gaussoin RE, 2011. Establishment and turf qualities of warm-season turfgrasses in the Mediterranean Region. HortTech. 21:67-81.

Shahba MA, 2010. Comparative responses of bermudagrass and seashore paspalum cultivars commonly used in Egypt to combat salinity stress. Hort. Environ. Biotechnol. 51:383-90.

Stiglbauer JB, Liu H, McCarty LB, Park DM, Toler JE, 2013. Seashore paspalum green establishment affected by sprig rates, nitrogen sources and rates. Int. Turfgrass Soc. Res. J. 12:251-6.

Trenholm LE, Carrow RN, Duncan RR, 1998. Paspalum vs. bermudagrass: which is more traffic tolerant? Golf Course Manage. 7:61-4.

Trenholm LE, Carrow RN, Duncan RR, 2000. Mechanisms of wear tolerance in seashore paspalum and bermudagrass. Crop Sci. 40:1350-7.

Trenholm LE, Duncan RR, Carrow RN, 1999. Wear tolerance, shoot performance, and spectral reflectance of seashore paspalum and bermudagrass. Crop Sci. 39:1147-52.

Volterrani M, Grossi N, Lulli F, Gaetani M, 2008. Establishment of warm season turfgrass species by transplant of single potted plants. Acta Hort. 783:77-84.

Volterrani M, Grossi N, Pardini G, Miele S, Gaetani M, Magni S, 1997. Warm season turfgrass adaptation in Italy. Int. Turfgrass Soc. Res. J. 8:1344-54.

Volterrani M, Magni S, Gaetani M, De Luca A, Croce P, Mocioni M, 2010. Bermudagrass evaluation trial in Italy. Proc. 2nd European Turfgrass Society Conference, Angers, France, pp. 222-4.

Volterrani M, Magni S, Lulli F, Mocioni M, Croce P, De Luca A, Grossi N, 2012. Converting bentgrass greens to hybrid bermudagrass by transplant of single potted plants. Proc. 3rd European Turfgrass Society Conference, Ås, Norway, pp. 102-3. 